\title{
Proximal deep vein thrombosis and pulmonary embolism in COVID-19 patients: a systematic review and meta-analysis
}

Gregoire Longchamp ${ }^{1}$ (D), Sara Manzocchi-Besson ${ }^{2,3}$, Alban Longchamp ${ }^{4,5}$, Marc Righini ${ }^{2}$, Helia Robert-Ebadi ${ }^{2}$ and Marc Blondon ${ }^{2^{*}}$

\begin{abstract}
Background: COVID-19 appears to be associated with a high risk of venous thromboembolism (VTE). We aimed to systematically review and meta-analyze the risk of clinically relevant VTE in patients hospitalized for COVID-19.

Methods: This meta-analysis included original articles in English published from January 1st, 2020 to June 15th, 2020 in Pubmed/MEDLINE, Embase, Web of science, and Cochrane. Outcomes were major VTE, defined as any objectively diagnosed pulmonary embolism (PE) and/or proximal deep vein thrombosis (DVT). Primary analysis estimated the risk of VTE, stratified by acutely and critically ill inpatients. Secondary analyses explored the separate risk of proximal DVT and of PE; the risk of major VTE stratified by screening and by type of anticoagulation.

Results: In 33 studies ( $n=4009$ inpatients) with heterogeneous thrombotic risk factors, VTE incidence was 9\% $\left(95 \% \mathrm{Cl} 5-13 \%, P^{2}=92.5\right)$ overall, and $21 \%(95 \% \mathrm{Cl} 14-28 \%, P=87.6 \%)$ for patients hospitalized in the ICU. Proximal lower limb DVT incidence was $3 \%\left(95 \% \mathrm{Cl} 1-5 \%, P^{2}=87.0 \%\right)$ and $8 \%\left(95 \% \mathrm{Cl} 3-14 \%, P^{2}=87.6 \%\right)$, respectively. $\mathrm{PE}$ incidence was $8 \%\left(95 \% \mathrm{Cl} 4-13 \%, P^{2}=92.1 \%\right)$ and $17 \%(95 \% \mathrm{Cl} 11-25 \%, P=89.3 \%)$, respectively. Screening and absence of anticoagulation were associated with a higher VTE incidence. When restricting to medically ill inpatients, the VTE incidence was 2\% (95\%Cl 0-6\%).

Conclusions: The risk of major VTE among COVID-19 inpatients is high but varies greatly with severity of the disease. These findings reinforce the need for the use of thromboprophylaxis in all COVID-19 inpatients and for clinical trials testing different thromboprophylaxis regimens in subgroups of COVID-19 inpatients.
\end{abstract}

Trial registration: The review protocol was registered in PROSPERO International Prospective Register of Systematic Reviews (CRD42020193369).

Keywords: Coronavirus, Venous thromboembolism, Thrombosis pulmonary embolism

\footnotetext{
* Correspondence: marc.blondon@hcuge.ch

${ }^{2}$ Division of Angiology and Haemostasis, Geneva University Hospitals and Faculty of Medicine, Rue Gabrielle-Perret-Gentil 4, 1205 Geneva, Switzerland

Full list of author information is available at the end of the article
}

(C) The Author(s). 2021 Open Access This article is licensed under a Creative Commons Attribution 4.0 International License, which permits use, sharing, adaptation, distribution and reproduction in any medium or format, as long as you give appropriate credit to the original author(s) and the source, provide a link to the Creative Commons licence, and indicate if changes were made. The images or other third party material in this article are included in the article's Creative Commons licence, unless indicated otherwise in a credit line to the material. If material is not included in the article's Creative Commons licence and your intended use is not permitted by statutory regulation or exceeds the permitted use, you will need to obtain permission directly from the copyright holder. To view a copy of this licence, visit http://creativecommons.org/licenses/by/4.0/ The Creative Commons Public Domain Dedication waiver (http://creativecommons.org/publicdomain/zero/1.0/) applies to the data made available in this article, unless otherwise stated in a credit line to the data. 


\section{Background}

Coronavirus disease 2019 (COVID-19) is caused by the severe acute respiratory syndrome coronavirus 2 (SARSCoV2). COVID-19 is characterized by vascular inflammation, with evidence of viral elements within endothelial cells [1]. Initial reports suggested an abnormal activation of coagulation, in particular with highly elevated D-dimer levels [2], which predicted a poor clinical prognosis and death $[3,4]$.

Since the start of the outbreak, several studies have highlighted a high risk of venous thromboembolism (VTE) in inpatients with COVID-19, up to 35-85\% and oftentimes despite pharmacological thromboprophylaxis $[5,6]$. However, such large estimates may emanate from the inclusion of small thrombi of uncertain clinical relevance, such as distal deep vein thrombosis (DVT), and may be more prone to being published with high visibility and publicized largely. A similar situation may be found in the lungs, where the vascular filling defects reported on computed tomography pulmonary angiography (CTPA) might reflect "immuno-thrombosis" or local "pulmonary thrombosis" rather than "classic" pulmonary embolism (PE).

Therefore, we aimed to systematically review the published literature on the risk of objectively diagnosed PE and/or proximal DVT - representing major VTE - in hospitalized patients with COVID-19. This information should help clinical decision and guidance with regards to thromboprophylaxis.

\section{Methods}

\section{Search strategy and study eligibility}

We performed this systematic review and meta-analysis in concordance with the Preferred Reporting Items for Systematic Reviews and Meta-Analyses (PRISMA) guidelines (additional table 1) [7]. The review protocol was registered in PROSPERO International Prospective Register of Systematic Reviews (CRD42020193369).

We searched for original articles in English language, in which the risk of major VTE could be estimated among COVID-19 inpatients. As such, we excluded case reports or case series of VTE. Studies were assessed for eligibility, regardless of the sample size, population group/subgroup of COVID-19 inpatients, and study design (observational or interventional, retrospective or prospective). Studies were included if SARS-CoV2 was confirmed with a PCR or based on clinical and radiological examinations [8].

Only peer-reviewed literature was appraised, published from January 1st, 2020 to June 15th, 2020, in Pubmed/ MEDLINE, Embase, Web of science, and Cochrane. The electronic search was supplemented by a search of the Lancet COVID-19 Ressource Centre, JAMA COVID-19, the New England Journal of Medicine Coronavirus, the use of the "similar articles" function in Pubmed, and the screening of the references list of all relevant articles (additional file 1).

\section{Outcomes}

The primary outcome was the risk of major VTE, defined as any objectively confirmed PE and/or proximal DVT. Proximal DVT was defined as lower limb DVT occurring in the popliteal, femoral, iliac veins and/or inferior vena cava, regardless of the presence of a catheter, and confirmed by compression ultrasound (CUS) or CT phlebography. We therefore excluded distal DVT (below the popliteal trifurcation) and upper extremity DVT, the latter being almost always catheter-related and not associated with the same embolic potential as lower limb proximal DVT. PE had to be objectively confirmed by CTPA, ventilation/perfusion scintigraphy, the presence of a proximal DVT on lower limb CUS in a patient with clinical suspicion of PE, or a high clinical suspicion of $\mathrm{PE}$ with an acute right ventricular dilatation on echocardiography [9].

Secondary analyses explored the separate risk of proximal DVT and of PE, as well as the risk of major VTE stratified by the presence or absence of VTE screening tests and by anticoagulation regimen.

\section{Data extraction and quality assessment}

The search, data extraction, and quality assessment were independently conducted in pairs by four authors (GL, $\mathrm{AL}, \mathrm{SMB}$ and $\mathrm{MB}$ ). Any disagreements were discussed until a consensus was reached, and solved by a third author (MR) whenever necessary.

Data were entered into a predesigned database, and included information on study design, setting, inclusion/ exclusion criteria, patients characteristics, diagnostic methods for COVID-19, VTE diagnosis, VTE screening strategy, and the use of therapeutic anticoagulation or thromboprophylaxis. Whenever necessary, an email was sent to the corresponding author for additional details (of the 24 authors contacted, 15 answered).

The risk of bias was assessed using the NewcastleOttawa scale for non-randomized clinical trials (additional table 2) [10].

\section{Statistical analysis}

The primary analysis estimated the risk of major VTE among studies including all inpatients - general medical wards and critical care units - and among studies including only intensive care unit (ICU) patients. This was computed by dividing the number of major VTE by the number of patients at risk at the start of the study. We did not consider Kaplan-Meier estimates, given their overestimating bias in case of competing risk of death. 
In the secondary analyses, we explored the separate risk of proximal DVT and of PE; the heterogeneity; the risk of major VTE with and without screening for DVT; the risks of VTE among patients receiving therapeutic anticoagulation, thromboprophylaxis and no anticoagulant treatment; and the risk of VTE among medical patients, by excluding ICU patients.

In a sensitivity analysis, we repeated the primary analysis in a restricted sample of high-quality studies defined as retrospective or prospective studies with an unselected group of medical and/or ICU patients, with a reported $\geq 80 \%$ of PCR positivity and a reported mean follow-up of at least 7 days.

All meta-analytic estimates were pooled using random effect models, because of expected substantial heterogeneity due to different sampling characteristics. Risks (proportions) observed in studies were transformed with the Freeman-Tukey double arcsin method to remove the dependence of the variance on the mean of the transformed proportion and to correct for overdispersion of estimates [11]. Heterogeneity itself was measured by using the $I^{2}$, describing the proportion of the observed between-studies variation not due to chance. Smallstudy effects were explored graphically with funnel plots and with Egger's tests.

All analyses were conducted in Microsoft Excel, Stata version 11 (including with the package metaprop) and R.

\section{Results}

\section{Study selection and characteristics}

Electronic database searches identified 890 titles and abstracts (Fig. 1). After removal of duplicates, 531 papers remained. Reviewing titles and abstracts resulted in 158 potential articles to be included. After full-text reading, 33 studies [6, 12-43] were included in the systematic review and meta-analysis (substantial agreement: Cohen's Kappa $=0.79$ ). No additional articles were identified by other sources of screening or by reviewing the relevant reference lists.

28 studies [13-27, 29-32, 34-41, 43] were conducted in Europe, three $[12,28,33]$ in the USA, and two $[6,42]$ in Asia (Table 1). 19 [12-15, 17, 21-23, 26, 28-31, 33$35,37,38,40]$ were retrospective cohorts, $12[16,18,20$, $24,25,27,32,36,39,41-43]$ were prospective cohorts, and two $[6,19]$ were cross-sectional studies. $19[6,13$, $15,16,21,23,27-30,32,33,36-41,43]$ reported VTE in the ICU, while 14 studies [12, 14, 17-20, 22, 24-26, $31,34,35,42]$ reported on a mixed population of medical ward and ICU patients.

The 33 studies included 4009 patients, with a range of mean age of 57-69 years, and proportion of women of 13.8-48.3\%. The prevalence of VTE risk factors varied widely: a personal history of VTE was reported in 3.0\% of patients (range 0-7.6\%), D-dimer levels ranged from $394 \mu \mathrm{g} / \mathrm{L}$ to $8300 \mu \mathrm{g} / \mathrm{L}$. Detailed characteristics of individual studies are found in the additional tables 3 and 4 .

\section{Quality assessment}

The Newcastle-Ottawa scale was used to assess risk of bias in each included study (additional table 2), excluding the items referring to the control group. Additionally, none of the studies demonstrated that the outcome of interest was not present at the start of the study. All studies met criteria for outcome assessment; consequently, the score ranged from one to 5 stars. 12 [12, 20, $22-25,28,30,34,36,38,41]$ and $8[6,15,18,19,26,39$, $42,43]$ studies were allocated three and two stars, respectively (Table 1). 7 [14, 21, 29, 31-33, 40] and 4 studies $[17,27,35,37]$ reached 4 and 5 stars, respectively;

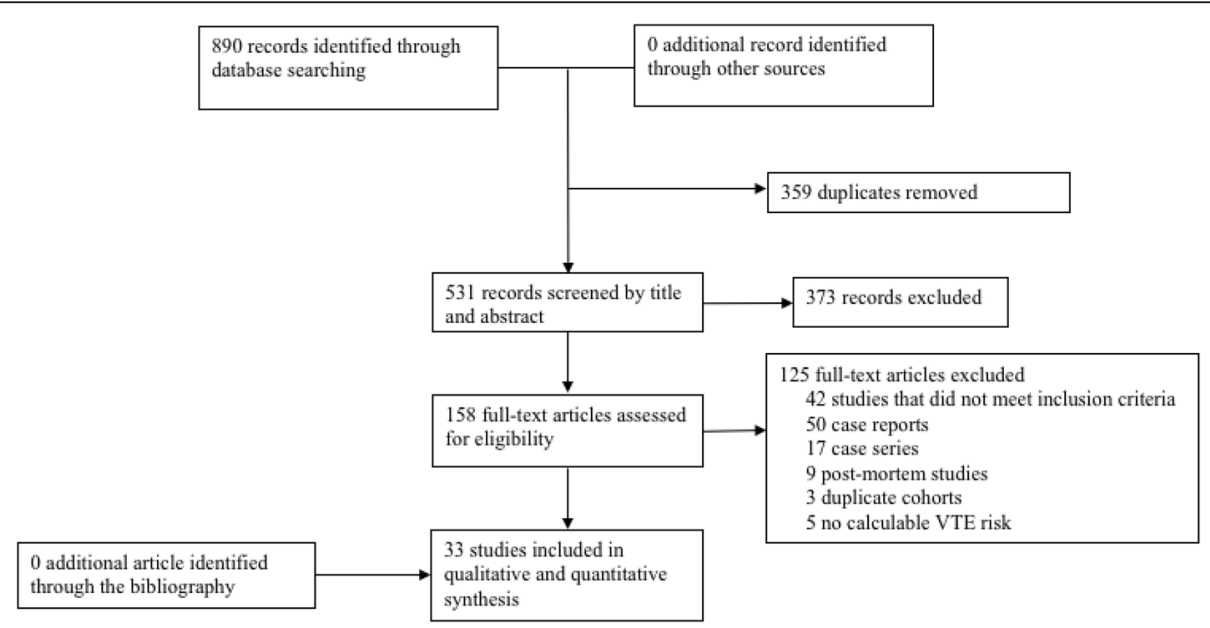

Fig. 1 Preferred Reporting Items for Systematic Reviews and Meta-analyses (PRISMA) flowchart showing selection of publication for review and meta-analysis. VTE = venous thromboembolism 
Table 1 Characteristics of included studies

\begin{tabular}{|c|c|c|c|}
\hline & $\begin{array}{l}\text { All studies, mean (range) } \\
\text { or } n(\%) \\
(n=33)\end{array}$ & $\begin{array}{l}\text { Mixed ward + ICU studies, mean (range) } \\
\text { or } n(\%)(n=14)\end{array}$ & $\begin{array}{l}\text { ICU studies, mean (range) or } n \\
(\%)(n=19)\end{array}$ \\
\hline \multicolumn{4}{|l|}{ Continent } \\
\hline - Europe & $28(84.9 \%)$ & $12(85.7 \%)$ & $16(84.2 \%)$ \\
\hline - USA & $3(9.1 \%)$ & $1(7.1 \%)$ & $2(10.53 \%)$ \\
\hline - Asia & $2(6.1 \%)$ & $1(7.1 \%)$ & $1(5.26 \%)$ \\
\hline \multicolumn{4}{|l|}{ Study design } \\
\hline - Retrospective cohort & $19(57.6 \%)$ & $8(57.1 \%)$ & $11(57.9 \%)$ \\
\hline - Prospective cohort & $12(36.4 \%)$ & $5(35.7 \%)$ & $7(36.84 \%)$ \\
\hline - Cross-sectional & $2(6.1 \%)$ & $1(7.1 \%)$ & $1(5.3 \%)$ \\
\hline \multicolumn{4}{|l|}{ NOS } \\
\hline - 等 & $2(6.1 \%)$ & 0 & $2(10.5 \%)$ \\
\hline 一负资 & $8(24.2 \%)$ & $4(28.6 \%)$ & $4(21.1 \%)$ \\
\hline 一察等负 & $12(36.4 \%)$ & $6(42.9 \%)$ & $6(31.6 \%)$ \\
\hline 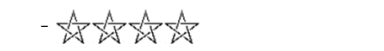 & $7(21.2 \%)$ & $2(14.3 \%)$ & $5(26.3 \%)$ \\
\hline 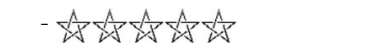 & $4(12.1 \%)$ & $2(14.3 \%)$ & $2(10.5 \%)$ \\
\hline $\mathrm{n}$ total & 4009 & 2747 & 1262 \\
\hline n per study & $121(10-785)$ & $196(25-785)$ & $66(10-184)$ \\
\hline n VTE total & 429 & 170 & 259 \\
\hline Age, years & $\begin{array}{l}64(57-69) \\
{[\text { missing }=10]}\end{array}$ & $\begin{array}{l}66(61-71) \\
{[\text { missing }=4]}\end{array}$ & $\begin{array}{l}63(57-70) \\
{[\text { missing = 6] }}\end{array}$ \\
\hline Women & $\begin{array}{l}31.8 \%(13.8-48.3 \%) \\
{[\text { missing = 8] }}\end{array}$ & $34.2 \%(13.8-48.3 \%)[$ missing $=3]$ & $\begin{array}{l}30.0 \%(16.7-45.8 \%) \\
{[\text { missing }=5]}\end{array}$ \\
\hline CVD & $\begin{array}{l}21.3 \%(8.8-52 \%) \\
{[\text { missing = 19] }}\end{array}$ & $\begin{array}{l}23.0 \%(11.9-52 \%) \\
{[\text { missing }=9]}\end{array}$ & $\begin{array}{l}20.4 \%(8.8-48 \%) \\
{[\text { missing = 10] }}\end{array}$ \\
\hline HTN & $\begin{array}{l}48.0 \%(32-84.6 \%) \\
{[\text { missing }=17]}\end{array}$ & $\begin{array}{l}43.0 \%(32-62.5 \%) \\
{[\text { missing }=7]}\end{array}$ & $\begin{array}{l}51.8 \%(38.2-84.6 \%) \\
{[\text { missing =10] }}\end{array}$ \\
\hline $\mathrm{DM}$ & $\begin{array}{l}26.8 \%(4-44.6 \%) \\
{[\text { missing }=15]}\end{array}$ & $\begin{array}{l}19.2 \%(8-30.8 \%) \\
{[\text { missing }=6]}\end{array}$ & $\begin{array}{l}32.9 \%(4-44.6 \%) \\
{[\text { missing }=9]}\end{array}$ \\
\hline Body-mass index, $\mathrm{kg} / \mathrm{m} 2$ & $\begin{array}{l}28.9(23.6-34.8) \\
{[\text { missing = 18] }}\end{array}$ & $\begin{array}{l}27.0(23.6-30) \\
{[\text { missing }=8]}\end{array}$ & $\begin{array}{l}30.2(27.5-34.8) \\
{[\text { missing }=10]}\end{array}$ \\
\hline Cancer & $\begin{array}{l}6.2 \%(0-20 \%) \\
{[\text { missing }=17]}\end{array}$ & $\begin{array}{l}8.3 \%(3.5-20 \%) \\
\text { [missing }=6]\end{array}$ & $\begin{array}{l}4.0 \%(0-8 \%) \\
{[\text { missing }=11]}\end{array}$ \\
\hline Personal history of VTE & $\begin{array}{l}3.0 \%(0-7.6 \%) \\
{[\text { missing }=19]}\end{array}$ & $\begin{array}{l}2.9 \%(0-7.0 \%) \\
{[\text { missing }=8]}\end{array}$ & $\begin{array}{l}3.0 \%(0-7.6 \%) \\
{[\text { missing }=11]}\end{array}$ \\
\hline Smoking & $\begin{array}{l}19.1 \%(3.1-43.8 \%) \\
{[\text { missing }=24]}\end{array}$ & $\begin{array}{l}15.6 \%(3.1-43.8 \%) \\
{[\text { missing }=9]}\end{array}$ & $\begin{array}{l}2.5 \%(1.8-3.0 \%) \\
{[\text { missing }=15]}\end{array}$ \\
\hline \multicolumn{4}{|l|}{ Laboratory testing } \\
\hline - Baseline D-dimer, $\mu \mathrm{g} / \mathrm{L}$ & $\begin{array}{l}2352(394-8300) \\
{[\text { missing }=14]}\end{array}$ & $1808(458-3700)$ [missing = 6] & $\begin{array}{l}2748(394-8300) \\
{[\text { missing }=8]}\end{array}$ \\
\hline - Baseline fibrinogen, g/L & $\begin{array}{l}6.5(4.1-9) \\
{[\text { missing }=17]}\end{array}$ & $\begin{array}{l}5.2(4.8-5.9) \\
{[\text { missing }=11]}\end{array}$ & $\begin{array}{l}6.8(4.1-9) \\
{[\text { missing = 8] }}\end{array}$ \\
\hline - Baseline platelets, × $10[9] / L$ & $\begin{array}{l}233(187-318) \\
{[\text { missing = 18] }}\end{array}$ & $\begin{array}{l}235(187-286) \\
{[\text { missing }=8]}\end{array}$ & $\begin{array}{l}232(200-319) \\
{[\text { missing }=10]}\end{array}$ \\
\hline \multicolumn{4}{|l|}{ Anticoagulation } \\
\hline - Chronic anticoagulation & $\begin{array}{l}7.4 \%(0-26.9 \%) \\
\text { [missing }=21]\end{array}$ & $\begin{array}{l}6.8 \%(0-16 \%) \\
{[\text { missing }=9]}\end{array}$ & $\begin{array}{l}7.8 \%(0-27.0 \%) \\
\text { [missing }=12]\end{array}$ \\
\hline $\begin{array}{l}\text { - Therapeutic anticoagulation } \\
\text { during the study }\end{array}$ & $\begin{array}{l}10.4 \%(0-69.2 \%) \\
{[\text { missing }=10]}\end{array}$ & $\begin{array}{l}4.3 \&(0-16 \%) \\
{[\text { missing }=6]}\end{array}$ & $\begin{array}{l}13.6 \%(0-6.9 \%) \\
{[\text { missing }=4]}\end{array}$ \\
\hline - Prophylactic anticoagulation & $83.8 \%(0-100 \%)$ & $80.4 \%(20-100 \%)$ & $85.9 \%$ (30.8-100\%) \\
\hline
\end{tabular}


Table 1 Characteristics of included studies (Continued)

\begin{tabular}{|c|c|c|c|}
\hline & $\begin{array}{l}\text { All studies, mean (range) } \\
\text { or } n(\%) \\
(n=33)\end{array}$ & $\begin{array}{l}\text { Mixed ward + ICU studies, mean (range) } \\
\text { or } n(\%)(n=14)\end{array}$ & $\begin{array}{l}\text { ICU studies, mean (range) or } n \\
(\%)(n=19)\end{array}$ \\
\hline during the study & {$[$ missing $=11]$} & [missing $=5]$ & [missing $=4]$ \\
\hline \multicolumn{4}{|l|}{ ICU } \\
\hline - ICU hospitalization & $\begin{array}{l}76.4 \%(6.3-100 \%) \\
{[\text { missing = 7] }}\end{array}$ & $\begin{array}{l}26.6 \%(6.3-53.8 \%) \\
{[\text { missing }=5]}\end{array}$ & $100 \%(100-100 \%)$ \\
\hline - Mechanical ventilation & $\begin{array}{l}67.5 \%(10-100 \%) \\
{[\text { missing }=11]}\end{array}$ & $\begin{array}{l}25.2 \%(11.3-25.6 \%) \\
{[\text { missing = 8] }}\end{array}$ & $\begin{array}{l}83.3 \%(10-100 \%) \\
\text { [missing = 3] }\end{array}$ \\
\hline - Use of vasopressors & $\begin{array}{l}64.2 \%(32.1-88.5 \%) \\
{[m i s s i n g=25]}\end{array}$ & {$[$ missing $=14]$} & $\begin{array}{l}64.2 \%(32.1-88.5 \%) \\
{[\text { missing }=11]}\end{array}$ \\
\hline - Hemodialysis & $\begin{array}{l}22.9 \%(14.7-37.1 \%) \\
{[\text { missing }=27]}\end{array}$ & [missing $=14]$ & $\begin{array}{l}22.9 \%(14.7-37.1 \%) \\
{[\text { missing }=13]}\end{array}$ \\
\hline - ECMO & $\begin{array}{l}16.9 \%(0-100 \%) \\
{[m i s s i n g=24]}\end{array}$ & $\begin{array}{l}0 \%(0-0 \%) \\
{[\text { missing = 13] }}\end{array}$ & $\begin{array}{l}19.1 \%(0-100 \%) \\
{[\text { missing }=11]}\end{array}$ \\
\hline
\end{tabular}

$\mathrm{ICU}=$ intensive care unit, NOS = Newcastle-Ottawa scale, VTE = venous thromboembolism, CVD = cardiovascular disease, HTN $=$ hypertension DM = diabetes mellitus, ECMO = extracorporeal membrane oxygenation

while the lowest score (one star) was obtained by two studies $[13,16]$.

\section{Venous thromboembolism incidence Primary analysis}

In 14 studies [12, 14, 17-20, 22, 24-26, 31, 34, 35, 42] in COVID-19 patients from medical ward \pm ICU, the pooled estimate of major VTE (proximal lower limb DVT and/or PE) incidence was 9\% (95\%CI 5-13\%, $I^{2}=$ 92.5) (Table 2, Fig. 2a). This rate was greater, at $21 \%$, when restricting the analysis to patients hospitalized in the ICU (19 studies, 95\%CI 14-28\%, $I^{2}=87.6 \%$, Table 2, Fig. 2a). The funnel plot appeared asymmetric for the 14 studies from medical ward \pm ICU (Egger test $p=0.02$ ), but appeared more symmetric for the 19 studies in the ICU (Egger test $p=0.47$, additional Figs. 1a-b). This suggested that small studies tended to report higher risk estimates than larger studies, and were potentially more prone to be published.

\section{Secondary analyses}

Proximal DVT Proximal lower limb DVT confirmed by CUS was reported in 24 studies $[6,12,14,16,18-25,27$, $29,31,32,34-38,40-42]$; with a pooled estimated incidence of $3 \%(95 \% \mathrm{CI} 1-5 \%)$ in the medical ward \pm ICU patients, and $8 \%(95 \% \mathrm{CI} 3-14 \%)$ when restricting to ICU patients (Table 2, additional figure 2a).
Pulmonary embolism PE was reported in 27 studies, as confirmed by CTPA [12-17, 21-35, 37-40, 42, 43], or as a clinical suspicion of PE associated with a thrombus in the right atrium on echocardiography [16, 30, 31]. The estimated incidence of $\mathrm{PE}$ was also lower in the mix of medical and ICU patients $(8,95 \% \mathrm{CI} 4-13 \%)$ than in the ICU only patients $(17,95 \%$ CI $11-25 \%)$ (Table 2 , additional figure 3a). From the $330 \mathrm{PE}$ reported in studies with data on location, $241(73 \%)$ were segmental or more proximal (30 (9\%) central, 39 (12\%) lobar, 100 (30\%) segmental, 72 (22\%) unspecified) and 56 (17\%) were subsegmental. The localization of PE was missing from 6 studies [24, 28, 30,31, 33, 42], accounting for 33 PE (10\%).

Heterogeneity We explored the heterogeneity found in all analyses, which emanated from different inclusion criteria, definition of VTE, duration of follow-up, screening, use of thromboprophylaxis. When examining outliers, Annunziata et al. [13] reported an $81 \%$ risk of PE (95\%CI 58-95\%) in a small, highly selected sample of 21 ICU patients with disseminated intravascular coagulation. Beyls et al. [16], another outlier, reported a high DVT incidence of $42 \%$ (95\%CI $15-72 \%)$ in a small sample of 12 ICU patients under ECMO. Furthermore, estimated VTE incidence from Mazzaccaro et al. [34] was $66 \%$, based on a systematic CTPA and CUS screening of 32 patients admitted to medical ward. However, when

Table 2 Meta-analytic estimates of the risk of VTE, stratified by location

\begin{tabular}{|c|c|c|c|c|c|c|}
\hline & \multicolumn{2}{|l|}{ VTE } & \multicolumn{2}{|l|}{ DVT } & \multicolumn{2}{|l|}{$\mathrm{PE}$} \\
\hline & ES $(95 \% \mathrm{Cl})$ & $1^{2}$ & ES $(95 \% \mathrm{Cl})$ & $1^{2}$ & ES (95\%Cl) & $1^{2}$ \\
\hline Medical ward \pm ICU & $9 \%(5-13 \%)$ & $92.5 \%$ & $3 \%(1-5 \%)$ & $87.0 \%$ & $8 \%(4-13 \%)$ & $92.1 \%$ \\
\hline ICU & $21 \%(14-28 \%)$ & $87.6 \%$ & $8 \%(3-14 \%)$ & $87.6 \%$ & $17 \%(11-25 \%)$ & $89.3 \%$ \\
\hline
\end{tabular}

VTE venous thromboembolism, DVT deep venous thrombosis, $P E$ pulmonary embolism, ICU intensive care unit 
a

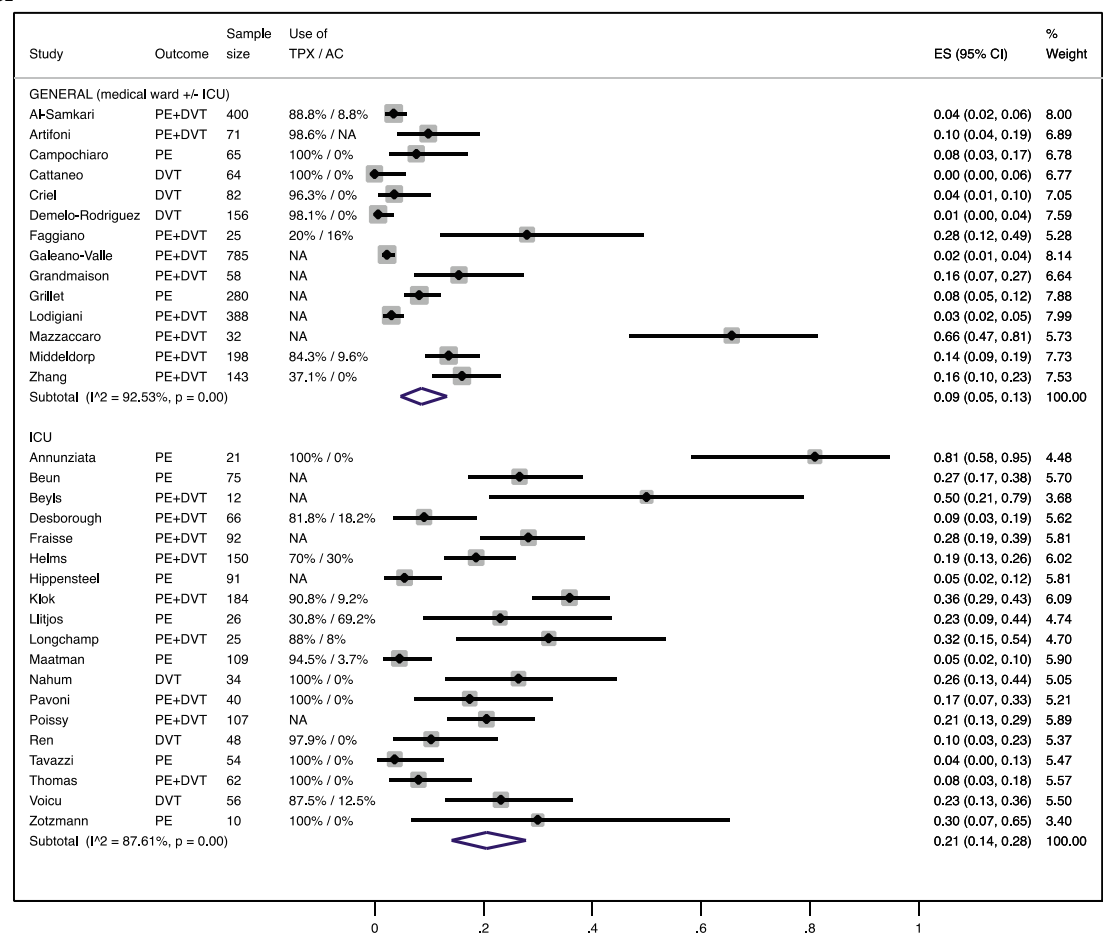

b

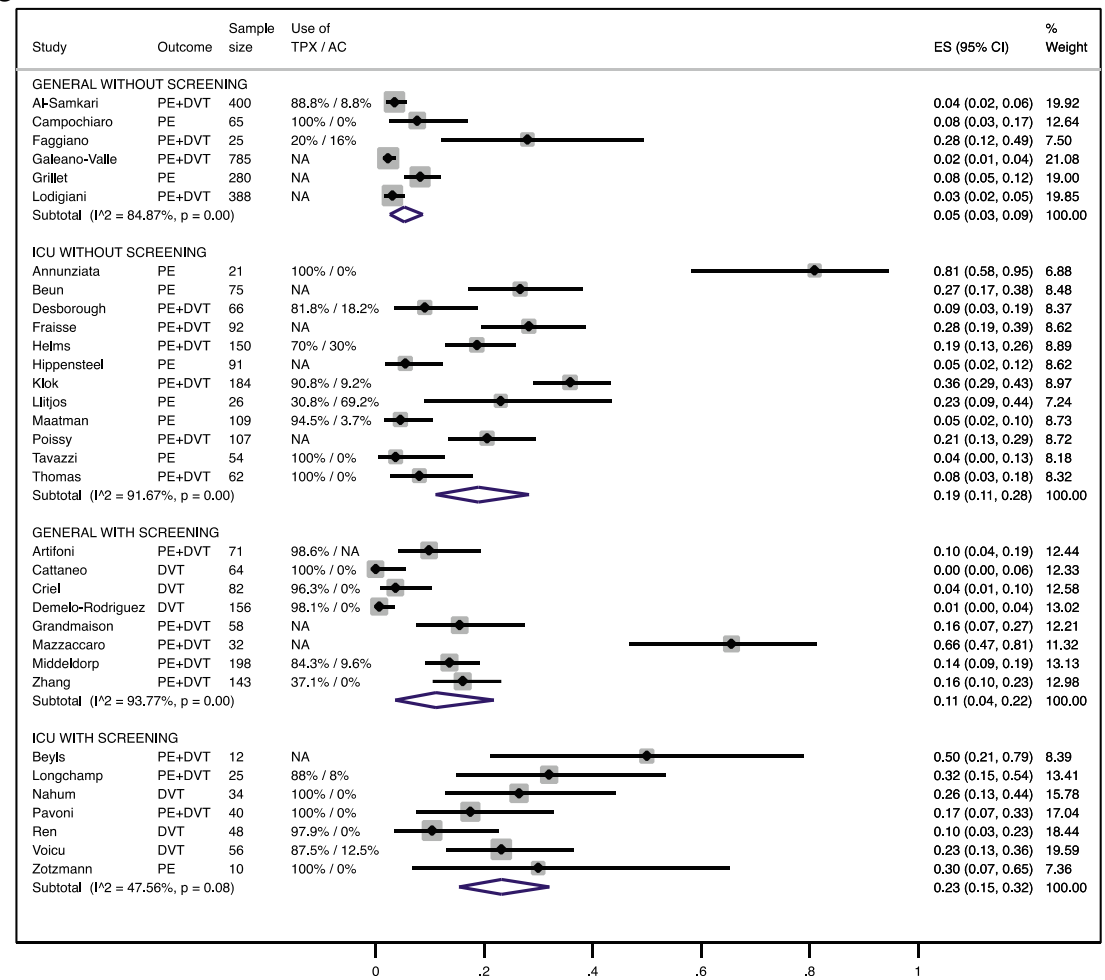

Fig. 2 Forrest plot of the estimated incidence of VTE: 2a stratified by medical ward and ICU; $2 \mathrm{~b}$ stratified by location and screening.TPX = thromboprophylaxis, $\mathrm{AC}=$ therapeutic anticoagulation, $\mathrm{ICU}=$ intensive care unit, $\mathrm{PE}=$ pulmonary embolism, $\mathrm{DVT}=$ deep vein thrombosis, $N A=$ not available 
excluding these three studies, the measured heterogeneity $\left(I^{2}\right)$ remained $>80 \%$ in the primary analysis.

Screening Screening for VTE was performed in 14 studies $[6,14,16,18-20,25,32,34-37,41,42]$ for DVT and three studies $[16,34,43]$ for PE. Overall, studies with implemented screening found higher risks of VTE than studies without screening. In the ICU, VTE rate was $23 \%$ vs. $19 \%$ respectively; and in combined medical ward and ICU, it was $11 \%$ vs. $5 \%$ respectively (Table 3, Fig. $2 \mathrm{~b}$, additional figures $2 \mathrm{~b}$ and $3 \mathrm{~b}$ for DVT and PE separately).

Anticoagulation Thrombotic events where further stratified by the type of anticoagulation during hospitalization, despite a large amount of missingness. In the absence of anticoagulation, with prophylactic and with therapeutic anticoagulation, proportions of VTE were 29.4\% [22, 32] (5/17), 19.8\% [13, 14, 17, 18, 22, 29, 32, 35-37, 39, 40, 43] $(155 / 781)$ and $7.1 \%[22,29,32,35](3 / 42)$, respectively (Fisher $p=0.047$ ) (additional table 5).

Risk among medical patients only 4 studies $[19,25$, 31,35 ] provided data to estimate the risk of VTE after exclusion of ICU patients. Among 531 medical patients, the meta-analytic risk of VTE was $2 \%(95 \%$ CI $0-6 \%)$ (additional figure 4).

\section{Sensitivity analyses}

In 8 high-quality studies [17, 21, 27, 31, 32, 35, 37, 40], the VTE incidence was $15 \%$ (95\%CI 9-23\%) in the ICU only versus $7 \%(95 \% \mathrm{CI} 2-17 \%)$ in the medical ward \pm ICU (additional figure 5a). Screening was also associated with a greater incidence: $14 \%$ versus $3 \%$ in the medical ward \pm ICU, and $23 \%$ versus $12 \%$ in the ICU only, with and without screening; respectively (additional figure $5 b)$.

\section{Discussion}

In this systematic review and meta-analysis, we extracted data from 33 studies including a total of 4009 patients. Among patients with COVID-19 hospitalized in the medical ward and/or ICU, the incidence of major VTE was $9 \%$. The incidence of proximal lower limb DVT was $3 \%$ and the incidence of PE $8 \%$. In ICU patients, corresponding incidences were much higher: 21,8 , and $17 \%$, respectively. When restricting the analysis to medical patients, VTE was only found in $2 \%$.

Previous meta-analytic efforts may have overestimated the burden of clinically relevant VTE among hospitalized patients with COVID-19. Among 30 studies published until June 24th, 2020, Porfidia et al. [44] reported an overall incidence of VTE of $26 \%$ (95\%CI 1-75\%), but upper extremity and distal lower limb DVT were also included. Nopp et al. [45] recently published the largest meta-analysis to date, including 66 studies with a total of 28,193 patients. Similarly to our report, they estimated an overall VTE risk of $14.1 \%$ (95\%CI 11.6-16.9\%), however they did not distinguish distal/proximal, and upper/lower limb DVT. Other meta-analyses have been published, but did not restrict the events to objectively diagnosed VTE, with a potential for overestimation of the risk of VTE [44-47].

The novelty of our analysis lies in the strict inclusion of objectively diagnosed clinically relevant VTE, restricted to proximal lower limb DVT and PE. Indeed, the clinical significance of distal DVT and need for anticoagulant treatment is highly debated, as its potential for embolism and recurrence is much lower than that of proximal DVT [48], without demonstrated benefit of anticoagulation in the limited randomized trials $[49,50]$. The same rationale applies to catheter-related upper extremity DVT. Moreover, the diagnostic performance of CUS is lower for distal DVT than for proximal DVT, with a potential for false positive and negative findings, so that restricting the analysis to proximal DVT is likely to provide more robust data on the true DVT rate. We a priori decided to include incidental PE in the primary outcome, because the current evidence suggests that it carries the same VTE recurrence rate, and therefore clinical significance, as symptomatic PE [51]. In any case, data on symptoms of VTE were limited, being reported by 9 studies $[14,18,20,21,32,35,37,41$, 43] for DVT, and 4 studies [16, 35, 40, 43] for PE.

Even when using these strict criteria for defining major VTE, we found an elevated risk of VTE in critically-ill COVID-19 patients (21\%), despite the use of pharmacological thromboprophylaxis in most studies. This is

Table 3 Meta-analytic estimates of the risk of VTE, stratified by location and screening

\begin{tabular}{|c|c|c|c|c|c|c|}
\hline & \multicolumn{2}{|l|}{ VTE } & \multicolumn{2}{|l|}{ DVT } & \multicolumn{2}{|l|}{$\mathrm{PE}$} \\
\hline & ES $(95 \% C l)$ & $1^{2}$ & ES $(95 \% \mathrm{Cl})$ & $1^{2}$ & ES $(95 \% C l)$ & $1^{2}$ \\
\hline Ward \pm ICU without screening & $5 \%(3-9 \%)$ & $84.9 \%$ & $1 \%(0-1 \%)$ & $27.9 \%$ & $5 \%(3-8 \%)$ & $83.7 \%$ \\
\hline Ward \pm ICU with screening & $11 \%(4-22 \%)$ & $93.8 \%$ & $4 \%(1-9 \%)$ & $83.3 \%$ & $66 \%(47-81 \%)$ & - \\
\hline ICU without screening & 19\% (11-28\%) & $91.7 \%$ & $2 \%(0-4 \%)$ & $52.4 \%$ & $17 \%(10-26 \%)$ & $90.6 \%$ \\
\hline ICU with screening & $23 \%(15-32 \%)$ & $47.6 \%$ & $20 \%(13-28 \%)$ & $44.2 \%$ & $17 \%(3-37 \%)$ & - \\
\hline
\end{tabular}

VTE venous thromboembolism, DVT deep venous thrombosis, PE pulmonary embolism, ICU intensive care unit 
much greater than the anticipated risk of VTE in ICU patients (5-9\%) inferred from previous studies of unselected ICU patients [52, 53]. We hypothesize that, in addition to COVID-19 specific pathophysiological mechanisms such as the endothelial tropism [1] and associated coagulopathy, extrinsic factors observed in these patients such as prolonged immobility and repetitive use of muscle relaxant drugs (curare) in COVID-19 patients with acute respiratory distress syndrome (ARDS), may contribute to this increased VTE rate compared to historical ICU cohorts. Among COVID-19 patients hospitalized in general medical wards, we found a $2 \%$ risk that is in line with previous estimates of VTE [54], but this analysis excluded participants who became critically ill during their hospital stay, and likely does not apply to medical patients with severe COVID-19 at the time of admission.

The utility of VTE screening remains unknown among COVID-19 inpatients. While we found greater VTE risks in studies which included some screening, usually for DVT, we cannot infer from our results that screening is useful and should be implemented in routine practice, given the lack of comparison within individual studies. This deserves further research.

The findings of our meta-analysis call for interventional clinical trials in this setting and supports the research effort that has been launched since the beginning of the epidemic. In particular, 20 trials are comparing different levels of anticoagulation to prevent the burden of VTE and reduce the respiratory failure associated with ARDS [55]. Our group has launched the ongoing Swiss multicentric COVID-HEP trial last April, which includes both ICU patients and medical patients deemed at poor prognosis due to elevated levels of D-dimer (NCT04345 848).

Strengths of this analysis include its wide search strategy, the independent selection of studies and abstraction of data, the contact with authors to request additional data and the inclusion of only VTE events with strict criteria on objective diagnosis and clinical relevance. We also acknowledge limitations. First, our search strategy was performed on June 15th, thus excluding the additional evidence published since then. However, this delay was inevitable in order to extract the outcome of interest, oftentimes with the help of multiple investigators. Second, as others, we observed a very important heterogeneity of all results, that was multifactorial. In particular, there was evident heterogeneity between study characteristics, with a mixture of inclusion criteria, use of screening and/or levels of thromboprophylaxis and different follow-up. Third, as this is a study-level meta-analysis, we were often restricted by the amount of data available in the published papers, or shared by investigators.

\section{Conclusions}

In conclusion, this meta-analysis found that the risk of objectively confirmed clinically relevant VTE was overall 9\% in patients with COVID-19 admitted to hospital. As compared to a $2 \%$ VTE risk in patients hospitalized only in a general medical ward, the risk was much higher (21\%) in patients needing ICU care during their hospital stay. Such findings reinforce the need for a proper use of thromboprophylaxis in severe COVID-19 inpatients, and for interventional trials testing different thromboprophylaxis regimens.

\section{Abbreviations}

COVID-19: Coronavirus disease 2019; SARS-CoV2: Severe acute respiratory syndrome coronavirus 2; VTE: Venous thromboembolism; DVT: Deep vein thrombosis; CTPA: Computed tomography pulmonary angiography; PE: Pulmonary embolism; PRISMA: Preferred Reporting Items for Systematic Reviews and Meta-Analyses; CUS: Compression ultrasound; ICU: Intensive care unit; ARDS: Acute respiratory distress syndrome

\section{Supplementary Information}

The online version contains supplementary material available at https://doi. org/10.1186/s12959-021-00266-X.

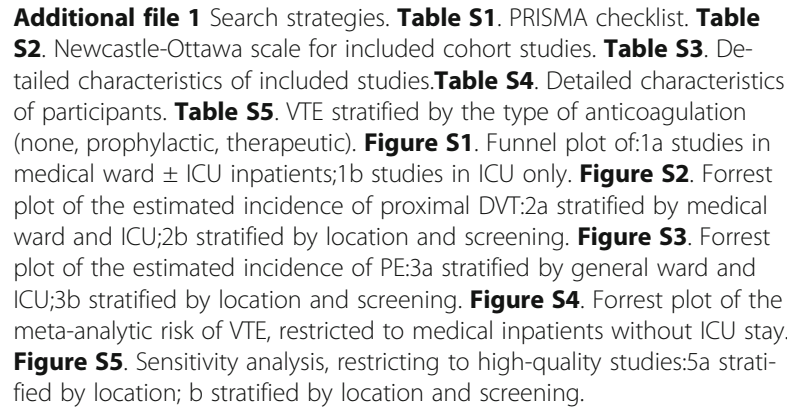

\section{Acknowledgements}

The authors thank Mafalda Burri for her contribution to the search strategy. Methodological support was provided by the Clinical Research Center, University of Geneva and Geneva University Hospitals (Christophe Combescure).

The authors thank Al-Samkari Hanny, Annunziata Anna, Artifoni Mathieu, Barco Stefano, Beyls Christophe, Contou Damien, Dagna Lorenzo, Faggiano Pompillio, Gianesello Lara, Grillet Franck, Helms Sophie, Mahjoub Yazine, Périard Daniel, Ruttens David, Susen Sophie, for their kind contribution of supplementary informations.

\section{Authors' contributions}

All authors designed the study. GL, AL, SMB and MB participated in data extraction. $\mathrm{GL}$ and $\mathrm{MB}$ conducted the analyses. GL drafted the manuscript. All authors critically revised the manuscript and accepted the final version of the manuscript.

\section{Funding}

Dr. A. Longchamp reports receiving grant support from the Swiss National Science Foundation (SNSF PZ00P3-185927).

\section{Availability of data and materials}

All data generated or analysed during this study are included in this published article and its supplementary information files. 


\section{Declarations}

\section{Ethics approval and consent to participate}

Not applicable.

\section{Consent for publication}

Not applicable.

\section{Competing interests}

The authors declare that they have no competing interests.

\section{Author details}

${ }^{1}$ Department of Visceral Surgery, Faculty of Medicine and Geneva University Hospitals, Geneva, Switzerland. ${ }^{2}$ Division of Angiology and Haemostasis, Geneva University Hospitals and Faculty of Medicine, Rue Gabrielle-Perret-Gentil 4, 1205 Geneva, Switzerland. ${ }^{3}$ Department of Vascular Surgery, Centre Hospitalier du Valais Romand de l'Hôpital du Valais (site de Sion), Sion, Switzerland. ${ }^{4}$ Department of Vascular Surgery, Centre Hospitalier Universitaire Vaudois and University of Lausanne, Lausanne, Switzerland. ${ }^{5}$ Department of Biomedical Sciences, University of Lausanne, Lausanne, Switzerland.

\section{Received: 3 November 2020 Accepted: 1 March 2021}

\section{Published online: 09 March 2021}

\section{References}

1. Varga Z, Flammer AJ, Steiger $P$, Haberecker M, Andermatt R, Zinkernagel AS, et al. Endothelial cell infection and endotheliitis in COVID-19. Lancet. 2020; 395(10234):1417-8

2. Levi M, Thachil J, Iba T, Levy JH. Coagulation abnormalities and thrombosis in patients with COVID-19. Lancet Haematol. 2020;7(6):e438-40.

3. Zhou F, Yu T, Du R, Fan G, Liu Y, Liu Z, et al. Clinical course and risk factors for mortality of adult inpatients with COVID-19 in Wuhan, China: a retrospective cohort study. Lancet Lond Engl. 2020:395(10229):1054-62.

4. Wang D, Hu B, Hu C, Zhu F, Liu X, Zhang J, et al. Clinical characteristics of 138 hospitalized patients with 2019 novel coronavirus-infected pneumonia in Wuhan, China. JAMA. 2020;323(11):1061-9.

5. Klok FA, Kruip MJHA, van der Meer NJM, Arbous MS, Gommers DAMPJ, Kant KM, et al. Incidence of thrombotic complications in critically ill ICU patients with COVID-19. Thromb Res. 2020;191:145-7.

6. Ren B, Yan F, Deng Z, Zhang S, Xiao L, Wu M, et al. Extremely high incidence of lower extremity deep venous thrombosis in 48 patients with severe COVID-19 in Wuhan. Circulation. 2020;142(2):181-3.

7. Moher D, Liberati A, Tetzlaff J, Altman DG, PRISMA Group. Preferred reporting items for systematic reviews and meta-analyses: the PRISMA statement. PLoS Med. 2009;6(7). https://doi.org/10.1371/journal.pmed.1 000097

8. Fang $Y$, Zhang $H$, Xie J, Lin M, Ying L, Pang P, et al. Sensitivity of chest CT for COVID-19: comparison to RT-PCR. Radiology. 2020;296(2):E115-7.

9. Konstantinides S, Meyer G, Becattini C, Bueno H, Geersing G, Harjola V, et al. 2019 ESC quidelines for the diagnosis and management of acute pulmonary embolism developed in collaboration with the European Respiratory Society (ERS). Eur Heart J. 2004;41:543-603.

10. Wells G, Shea B, O'Connell D, Peterson J, Welch V, Losos M et al. The Newcastle-Ottawa scale (NOS) for assessing the quality of nonrandomized studies in metaanalysis. 2009. Available from: http://www.ohri.ca/programs/ clinical_epidemiology/oxford.asp

11. Blondon M, Casini A, Hoppe KK, Boehlen F, Righini M, Smith NL. Risks of venous thromboembolism after cesarean sections: a meta-analysis. Chest. 2016 Sep;150(3):572-96.

12. Al-Samkari H, Karp Leaf RS, Dzik WH, Carlson JCT, Fogerty AE, Waheed A et al. COVID-19 and coagulation: bleeding and thrombotic manifestations of SARS-CoV-2 infection. Blood. 2020;136(4):489-500.

13. Annunziata A, Imitazione P, Polistina GE, Lanza M, Coppola A, Fiorentino G. Pulmonary embolism in Covid-19: coagulation parameters, close monitoring to prevent? Turk Thorac J. 2020;21(4):287-8.

14. Artifoni M, Danic G, Gautier G, Gicquel P, Boutoille D, Raffi F, et al. Systematic assessment of venous thromboembolism in COVID-19 patients receiving thromboprophylaxis: incidence and role of D-dimer as predictive factors. J Thromb Thrombolysis. 2020 Jul;:50(1):211-6.
15. Beun R, Kusadasi N, Sikma M, Westerink J, Huisman A. Thromboembolic events and apparent heparin resistance in patients infected with SARS-CoV2. Int J Lab Hematol. 2020;42(Suppl 1):19-20.

16. Beyls C, Huette P, Abou-Arab O, Berna P, Mahjoub Y. Extracorporeal membrane oxygenation for COVID-19-associated severe acute respiratory distress syndrome and risk of thrombosis. $\mathrm{Br} J$ Anaesth. 2020;125(2):e260-2.

17. Campochiaro C, Della-Torre E, Cavalli G, De Luca G, Ripa M, Boffini N, et al Efficacy and safety of tocilizumab in severe COVID-19 patients: a singleCentre retrospective cohort study. Eur J Intern Med. 2020;76:43-9.

18. Cattaneo M, Bertinato EM, Birocchi S, Brizio C, Malavolta D, Manzoni M, et al. Pulmonary embolism or pulmonary thrombosis in COVID-19? Is the recommendation to use high-dose heparin for Thromboprophylaxis justified? Thromb Haemost. 2020;120(8):1230-2.

19. Criel M, Falter M, Jaeken J, Van Kerrebroeck M, Lefere I, Meylaerts L, et al. Venous thromboembolism in SARS-CoV-2 patients: only a problem in ventilated ICU patients, or is there more to it? Eur Respir J. 2020. https://doi. org/10.1183/13993003.01201-2020.

20. Demelo-Rodríguez P, Cervilla-Muñoz E, Ordieres-Ortega L, Parra-Virto A, Toledano-Macías M, Toledo-Samaniego N, et al. Incidence of asymptomatic deep vein thrombosis in patients with COVID-19 pneumonia and elevated D-dimer levels. Thromb Res. 2020 May 13;192:23-6.

21. Desborough MJR, Doyle AJ, Griffiths A, Retter A, Breen KA, Hunt BJ. Imageproven thromboembolism in patients with severe COVID-19 in a tertiary critical care unit in the United Kingdom. Thromb Res. 2020;193:1-4.

22. Faggiano P, Bonelli A, Paris S, Milesi G, Bisegna S, Bernardi N, et al. Acute pulmonary embolism in COVID-19 disease: Preliminary report on seven patients. Int J Cardiol. 2020:313:129-31.

23. Fraissé $\mathrm{M}$, Logre $\mathrm{E}$, Pajot $\mathrm{O}$, Mentec $\mathrm{H}$, Plantefève $\mathrm{G}$, Contou D. Thrombotic and hemorrhagic events in critically ill COVID-19 patients: a French monocenter retrospective study. Crit Care. 2020;24(1):275

24. Galeano-Valle F, Oblitas CM, Ferreiro-Mazón MM, Alonso-Muñoz J, Del ToroCervera J, di Natale M, et al. Antiphospholipid antibodies are not elevated in patients with severe COVID-19 pneumonia and venous thromboembolism. Thromb Res. 2020;192:113-5.

25. Grandmaison G, Andrey A, Périard D, Engelberger RP, Carrel G, Doll S, et al. Systematic screening for venous thromboembolic events in COVID-19 pneumonia. Thromb Haemost Open. 2020;4(2):e113-5.

26. Grillet F, Behr J, Calame P, Aubry S, Delabrousse E. Acute pulmonary embolism associated with COVID-19 pneumonia detected by pulmonary CT angiography. Radiology. 2020;23:201544

27. Helms J, Tacquard C, Severac F, Leonard-Lorant I, Ohana M, Delabranche X, et al. High risk of thrombosis in patients with severe SARS-CoV-2 infection: a multicenter prospective cohort study. Intensive Care Med. 2020. https://doi. org/10.1007/s00134-020-06062-x

28. Hippensteel JA, LaRiviere WB, Colbert JF, Langouët-Astrié CJ, Schmidt EP. Heparin as a therapy for COVID-19: current evidence and future possibilities. Am J Physiol Lung Cell Mol Physiol. 2020;319(2):L211-7.

29. Klok FA, Kruip MJHA, van der Meer NJM, Arbous MS, Gommers D, Kant KM, et al. Confirmation of the high cumulative incidence of thrombotic complications in critically ill ICU patients with COVID-19: an updated analysis. Thromb Res. 2020. https://doi.org/10.1016/j.thromres.2020.04.041.

30. Llitjos J-F, Leclerc M, Chochois C, Monsallier J-M, Ramakers M, Auvray M et al. High incidence of venous thromboembolic events in anticoagulated severe COVID-19 patients. J Thromb Haemost. 2020. https://doi.org/10.1111/ jth. 14869

31. Lodigiani C, lapichino G, Carenzo L, Cecconi M, Ferrazzi P, Sebastian T, et al. Venous and arterial thromboembolic complications in COVID-19 patients admitted to an academic hospital in Milan, Italy. Thromb Res. 2020;191:9-14.

32. Longchamp A, Longchamp J, Manzocchi-Besson S, Whiting L, Haller C, Jeanneret $\mathrm{S}$, et al. Venous thromboembolism in critically ill patients with Covid-19: results of a screening study for deep vein thrombosis. Res Pract Thromb Haemost. 2020 Jul;4(5):842-7.

33. Maatman TK, Jalali F, Feizpour C, Douglas A, McGuire SP, Kinnaman G, et al. Routine venous thromboembolism prophylaxis may be inadequate in the Hypercoagulable state of severe coronavirus disease 2019. Crit Care Med. 2020;48(9):e783-90.

34. Mazzaccaro D, Giacomazzi F, Giannetta M, Varriale A, Scaramuzzo R, Modafferi A, et al. Non-overt coagulopathy in non-ICU patients with mild to moderate COVID-19 pneumonia. J Clin Med. 2020:9(6). https://doi.org/10.1 097/CCM.0000000000004466 
35. Middeldorp S, Coppens M, van Haaps TF, Foppen M, Vlaar AP, Müller MCA et al. Incidence of venous thromboembolism in hospitalized patients with COVID-19. J Thromb Haemost JTH. 2020;18(8):1995-2002.

36. Nahum J, Morichau-Beauchant T, Daviaud F, Echegut P, Fichet J, Maillet J-M, et al. Venous Thrombosis Among Critically III Patients With Coronavirus Disease 2019 (COVID-19). JAMA Netw Open. 2020;3(5):e2010478.

37. Pavoni V, Gianesello L, Pazzi M, Stera C, Meconi T, Frigieri FC. Evaluation of coagulation function by rotation thromboelastometry in critically ill patients with severe COVID-19 pneumonia. J Thromb Thrombolysis. 2020. https://doi. org/10.1007/s11239-020-02130-7.

38. Poissy J, Goutay J, Caplan M, Parmentier E, Duburcq T, Lassalle F, et al. Pulmonary embolism in COVID-19 patients: awareness of an increased prevalence. Circulation. 2020. https://doi.org/10.1007/s00134-020-06040-3.

39. Tavazzi G, Civardi L, Caneva L, Mongodi S, Mojoli F. Thrombotic events in SARS-CoV-2 patients: an urgent call for ultrasound screening. Intensive Care Med. 2020;46(6):1121-3.

40. Thomas W, Varley J, Johnston A, Symington E, Robinson M, Sheares K, et al. Thrombotic complications of patients admitted to intensive care with COVID-19 at a teaching hospital in the United Kingdom. Thromb Res. 2020 Apr 25;191:76-7.

41. Voicu S, Bonnin P, Stépanian A, Chousterman BG, Le Gall A, Malissin I, et al. High prevalence of deep vein thrombosis in mechanically ventilated COVID19 patients. J Am Coll Cardiol. 2020 Jul 28;76(4):480-2.

42. Li Z, Xiaokai F, Danqing Z, Chunguo J, Heng M, Wang J, et al. Deep vein thrombosis in hospitalized patients with coronavirus disease 2019 (COVID19) in Wuhan, China: prevalence, risk factors, and outcome. Circulation. 2020;142(2):114-28.

43. Zotzmann V, Lang CN, Bamberg F, Bode C, Staudacher DL. Are subpleural consolidations indicators for segmental pulmonary embolism in COVID-19? Intensive Care Med. 2020;46(6):1109-10.

44. Porfidia A, Valeriani E, Pola R, Porreca E, Rutjes AWS, Di Nisio M. Venous thromboembolism in patients with COVID-19: systematic review and metaanalysis. Thromb Res. 2020 Dec;196:67-74.

45. Nopp S, Moik F, Jilma B, Pabinger I, Ay C. Risk of venous thromboembolism in patients with COVID-19: A systematic review and meta-analysis. Res Pract Thromb Haemost. 2020. https://doi.org/10.1002/rth2.12439.

46. Lu Y, Pan L, Zhang W-W, Cheng F, Hu S-S, Zhang X, et al. A meta-analysis of the incidence of venous thromboembolic events and impact of anticoagulation on mortality in patients with COVID-19. Int J Infect Dis. 2020 Nov 1;100:34-41.

47. Di Minno A, Ambrosino P, Calcaterra I, Di Minno MND. COVID-19 and venous thromboembolism: a meta-analysis of literature studies. Semin Thromb Hemost. 2020. https://doi.org/10.1055/s-0040-1715456.

48. Eichinger $\mathrm{S}$, Heinze $\mathrm{G}$, Jandeck LM, Kyrle PA. Risk assessment of recurrence in patients with unprovoked deep vein thrombosis or pulmonary embolism: the Vienna prediction model. Circulation. 2010 Apr 13;121(14):1630-6.

49. Righini M, Galanaud J-P, Guenneguez H, Brisot D, Diard A, Faisse P, et al. Anticoagulant therapy for symptomatic calf deep vein thrombosis (CACT US): a randomised, double-blind, placebo-controlled trial. Lancet Haematol. 2016 Dec;3(12):e556-62.

50. Robert-Ebadi H, Righini M. Management of distal deep vein thrombosis. Thromb Res. 2017;149:48-55.

51. Spirk D, Sebastian T, Barco S, Banyai M, Beer JH, Mazzolai L, et al. Clinical outcomes of incidental venous thromboembolism in Cancer and noncancer patients: the SWlss venous ThromboEmbolism registry (SWIVTER). Thromb Haemost. 2020. https:/doi.org/10.1055/s-0040-1720977.

52. Cook D, Crowther M, Meade M, Rabbat C, Griffith L, Schiff D, et al. Deep venous thrombosis in medical-surgical critically ill patients: prevalence, incidence, and risk factors. Crit Care Med. 2005 Jul;33(7): 1565-71.

53. PROTECT Investigators for the Canadian Critical Care Trials Group and the Australian and New Zealand Intensive Care Society Clinical Trials Group, Cook D, Meade M, Guyatt G, Walter S, Heels-Ansdell D, et al. Dalteparin versus unfractionated heparin in critically ill patients. N Engl J Med. 2011; 364(14):1305-14

54. Blondon M, Spirk D, Kucher N, Aujesky D, Hayoz D, Beer JH, et al. Comparative performance of clinical risk assessment models for hospitalacquired venous thromboembolism in medical patients. Thromb Haemost. 2018;118(1):82-9.

55. Tritschler $T$, Mathieu M-E, Skeith $L$, Rodger M, Middeldorp S, Brighton T, et al. Anticoagulant interventions in hospitalized patients with COVID-
19: a scoping review of randomized controlled trials and call for international collaboration. J Thromb Haemost JTH. 2020. https://doi. org/10.1111/jth.15094.

\section{Publisher's Note}

Springer Nature remains neutral with regard to jurisdictional claims in published maps and institutional affiliations.
Ready to submit your research? Choose BMC and benefit from:

- fast, convenient online submission

- thorough peer review by experienced researchers in your field

- rapid publication on acceptance

- support for research data, including large and complex data types

- gold Open Access which fosters wider collaboration and increased citations

- maximum visibility for your research: over $100 \mathrm{M}$ website views per year

At $\mathrm{BMC}$, research is always in progress.

Learn more biomedcentral.com/submissions 